\title{
Proximate, fatty acid and Mineral composition of orange-spotted grouper Epinephelus coioides from Parangipettai coast
}

\author{
R. Anbarasu*, G. Sankar, T. Manikandarajan, K. Kathirvel, S. Suvitha, \\ K. Ramamoorthy
}

Centre of Advanced Study in Marine Biology, Faculty of Marine Sciences, Annamalai University, Parangipettai - 608 502, Tamil Nadu, India

*E-mail address: anbumarine01@gmail.com

Keywords: Epinephelus coioides; Fatty acids; Grouper fish and Minerals

\begin{abstract}
The marine fish are extraordinarily nourishing food and are affluently accessible fish meat source. Fresh examined sample of grouper fish was collected from Mudasal odai fish landing center. The protein, carbohydrate, lipid, ash and moisture contents of Epinephelus coioides were found to be $19.07 \mathrm{mg}, 4.03,2.61,77.38 \mathrm{mg}$ and $1.21 \mathrm{mg} / \mathrm{g}$ respectively. The potassium and phosphorus are the predominant elements other nine components are present in considerable quantities in the total of 11 minerals. Palmitic acid, Oleic acid and Stearic acid were observed to be the major elements of total presented 15 fatty acids. In this current study we have concluded the grouper fish having rich source of protein and good fatty acids and it will facilitate to enhance the nutrition level on poor folks.
\end{abstract}

\section{INTRODUCTION}

The marine edible fish source are extraordinarily nourishing food and are affluently accessible meat source in world-wide. In general, the consumption of marine food are most important things in our diet attributed by the marine fish that act as a primary supply of chief quality proteins, essential fatty acids and minerals. These kinds of dietary qualities aroused the rising demand for the fish [1]. Analysis of proximate composition offers information on the dietary value of a selected examined organism used as a good source of food [2]. The importance of the long chain poly unsaturated fatty acid (PUFA) has great attention because, it will forestall coronary-artery disease as well as heart diseases and very important for treating eye connected infections on human health. This fatty acids conjointly plays a key role in development of brain and also decrease the risk of breast cancer and chronic systemic inflammatory disorder [3]. Minerals are mainly involved on the growth of the fish owing to its elevated essential nutrients and parts of the various enzymes and metabolism [4].

Grouper fish are standard ranch in Southeast Asia and it is the good potential to become a very important aquaculture fish species because of their quick body growth, competent feed exchange and high market price. The orange-spotted grouper Epinephelus coioides also known as the estuary cod may be a species of fish in the Serranidae family. It's found in the Western pacific, Indian Ocean and also the Red Sea. Its natural habitats are semitropical or tropical mangrove forests, open seas, shallow seas, sub tidal sea beds, coral reefs, estuarine back waters, intertidal flats and coastal saline lagoons it's vulnerable by habitat loss.

The present study was concluding the proximate composition and nutrition worth of the grouper to support a rise consumption of these species in larger quantity of grouper fish.

\section{MATERIALS AND METHODS}

\subsection{Collection of sample}

Fresh samples of grouper fish was collected from Mudasal odai landing center. They were kept in cold ice box and immediately transported to the laboratory. In this sample, non edible parts like intestines, gills, liver and gonads were removed from the sample fish and edible portion alone 
was taken for the analysis. The sample was oven dried in an electric oven at between $70-80{ }^{\circ} \mathrm{C}$ until the samples get constant weight and used following procedure for the analysis.

\subsection{Estimation of Protein}

The Folin-Ciocalten Phenol method of Lowery et al. (1959) was used for the determination of the total protein in the tissue [5].

\subsection{Estimation of Lipids}

The lipid content was estimated by the procedure given by Folch et al., (1957) [6].

\subsection{Estimation of Carbohydrates}

The total carbohydrate was estimated by Phenol- Sulphuric acid method described by Dubois et al. (1956) [7].

\subsection{Estimation of Minerals}

The minerals were estimated by following the method of Guzman and Jimenez (1992) [8].

\subsection{Fatty acid analysis}

The lipids were extracted according to the method of Bligh and Dyer, (1959) [9] and the total fatty acid composition were determined by Gas Chromatography Chemito.

\section{RESULTS}

In this present investigation, the protein, carbohydrate, lipid, ash and moisture contents of $E$. coioides were found to be $19.07 \mathrm{mg}, 4.03,2.61,77.38 \mathrm{mg}$ and $1.21 \mathrm{mg} / \mathrm{g}$ respectively. The observed results clearly depicts that the $E$. coioides has the maximum protein content followed by the moderate carbohydrate and lipid contents. Figure 1 shows the proximate composition of orange spotted grouper fish.

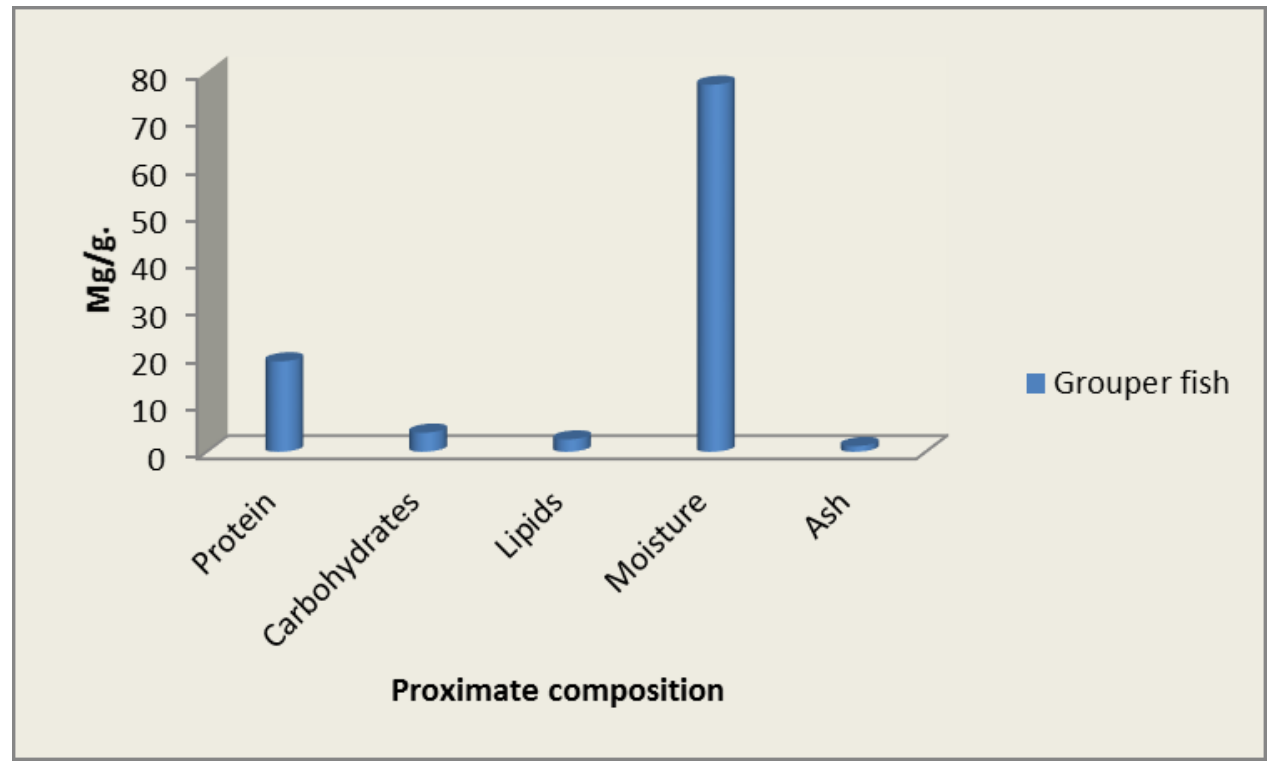

Figure 1: Proximate composition of E. coioides.

\subsection{Estimation of Minerals}

Totally 11 minerals were found in the examined fish. The potassium and phosphorus are the predominant and other nine components are present in considerable quantities elements in this fish sample. The results were mentioned in Figure 3. 


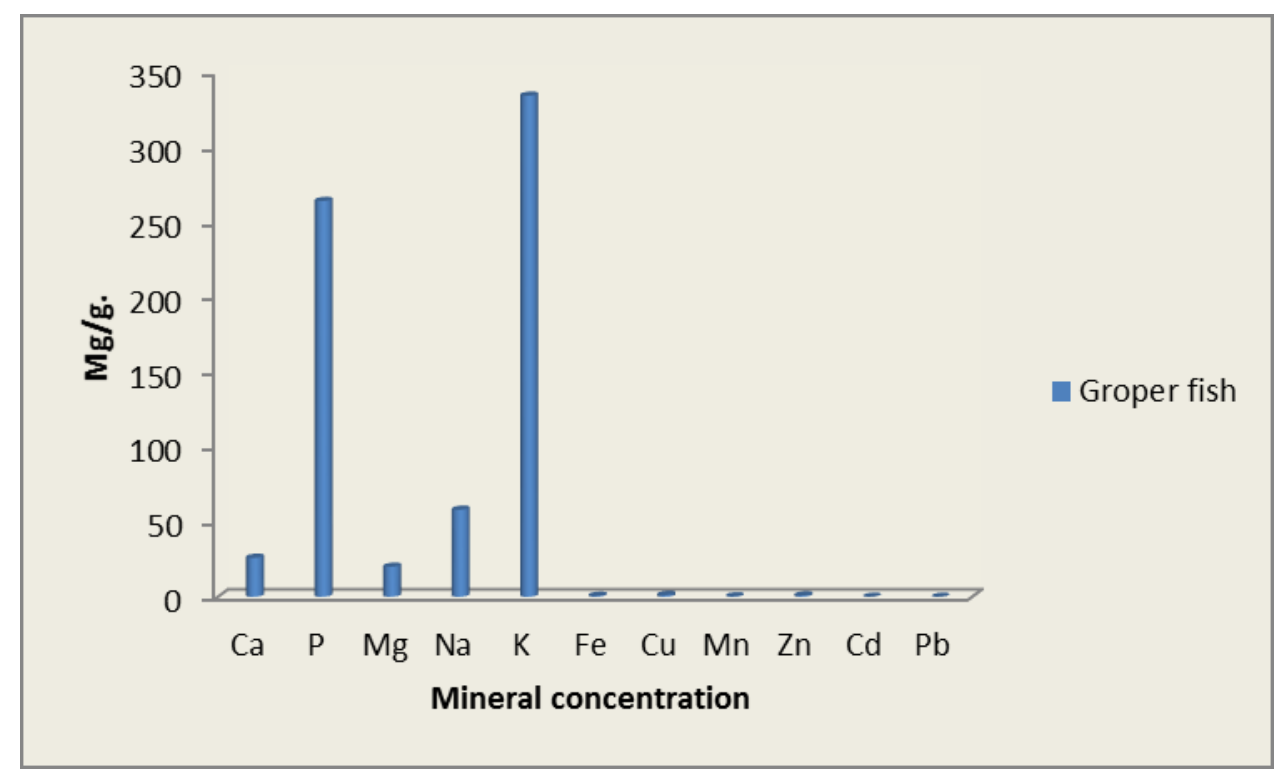

Figure 2: Mineral concentrations of E. coioides

\subsection{Estimation of Fatty acids}

In the present study the fatty acid concentration is the major element on investigated fish. In this study 15 fatty acids were found in E. coioides. In these species Palmitic acid, Oleic acid and Stearic acid were observed to be the major element. Results were showed on Figure 2.

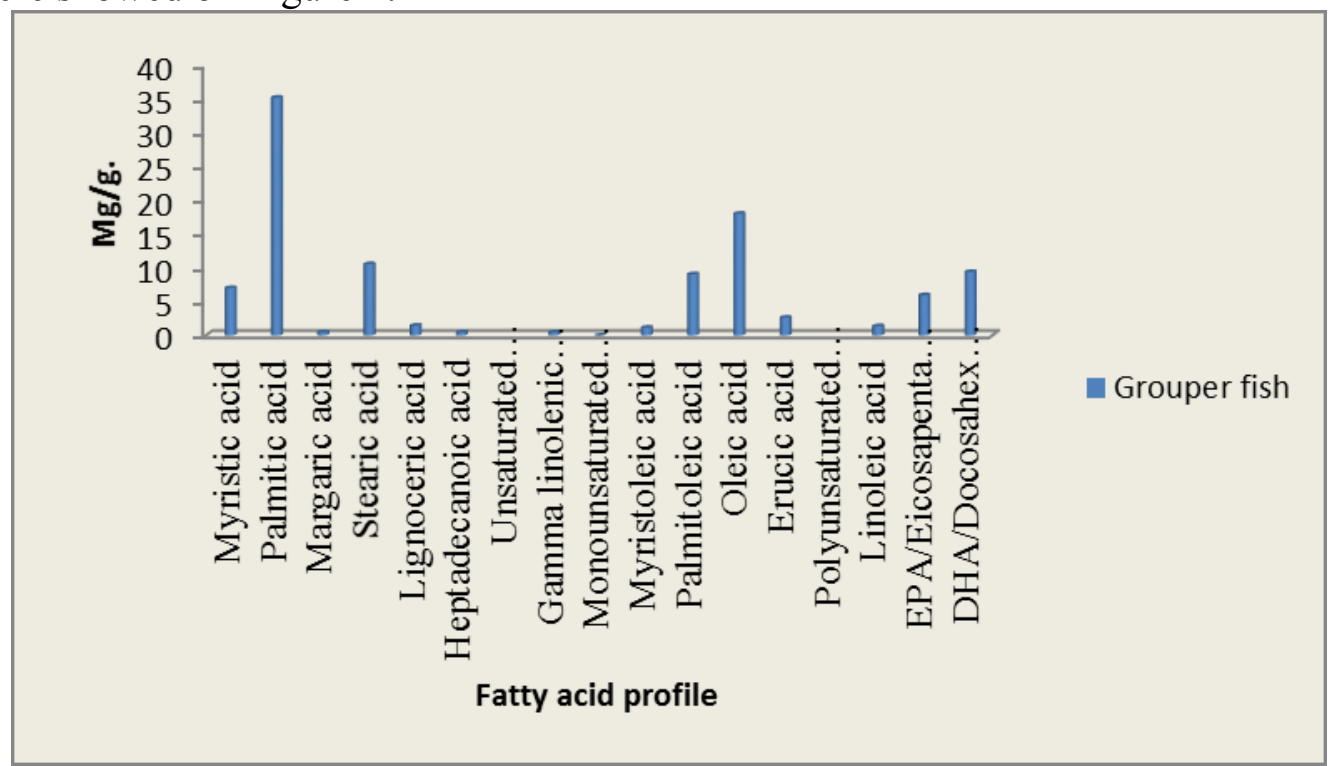

Figure 3: Fatty acid profile of E. coioides.

\section{DISCUSSION}

In this current study the protein content is higher than other elements. The proximate composition level was mentioned in Figure 1. The protein concentrations varied from one fish to another fish. Connected studies were conducted by several other researchers and recorded the protein concentrations as $17.56 \mathrm{mg} / \mathrm{g}$ at Mugil cephalus [10]. $9.22 \mathrm{mg} / \mathrm{g}$ at Lagocephalus lunaris 8.92 throughout Lagocephalus inermis and $17.58 \mathrm{mg}$ all through Raja clavata [11, 12]. In this investigation, grouper was having a lot of protein content than higher than observed fish species.

The carbohydrate level of the grouper fish was recorded to be in moderate level. Obonnya and Ibrahim observed the carbohydrate level on Clarios gariepinus as $5.48 \%, 2.78 \%$ and $3.84 \%$ by sight raw drying method, Kiln-dried method and electric dry method respectively on catfish [13]. 
The marine pelagic fish Fringe scale sardinella contained $3.07 \%$ of carbohydrate [14]. These variations could be attributed by the environmental changes.

The lipid composition of grouper fish was found superior concentrations from some other fish sample. M. cephalus has another 42 the worries [10a]. Manat et al., were recorded the fat level $0.54 \mathrm{~g}$ on dorsal, $4.21 \mathrm{mg} / \mathrm{g}$ on ventral and $8.60 \mathrm{mg} / \mathrm{g}$ on lateral line of Pangasianodon gigas [15]. Manikandarajan et al. were informed that the higher concentration of lipid on Plotosus lineatus has $66.93 \mathrm{gm}$ of lipid on body-part of cat fish [16]. This abundant variation happens owing to the food consumption pattern of fish species.

\subsection{Estimation of Minerals}

In general, the marine foods are having plentiful source of mineral contents. In this study, the grouper fish has vital source of Potassium $(\mathrm{K})$ and sodium $(\mathrm{Na})$ level. $\mathrm{K}$ is needed for the normal functioning of the nerves and muscle, the sugar metabolism, acid-base balance and oxygen metabolism in the brain. The heart also needs potassium. Na regulates the electrolyte and acid alkali balances, the conductive capability of the nerves, muscle contractions and the production of adrenaline and amino acids. In human, Na requirement is above $3 \mathrm{~g}$ per day. The majority have a $\mathrm{K}$ intake of between 2-4 g per day on the average [17]. In this present study totally 11 minerals were determined in grouper fish and Phosphorus, $\mathrm{K}$ are the predominant components. Fawole et al., studied the mineral concentration on Oreochromis niloticus $0.23 \%, 0.32 \%$, Sarotherodon galilaeus $0.25 \%, 0.34 \%$, Clarias gariepinus $0.34 \%, 0.36 \%$ and Heterotis niloticus $0.38 \%, 0.32 \%$ phosphorus and $\mathrm{K}$ respectively [18]. Kumaran et al analyzed $265 \mathrm{mg}$ of $\mathrm{K}$ on $M$. cephalus fish. In this study the $\mathrm{K}$ was $334.32 \mathrm{mg}$ [10b]. These variations were occurred might be the environmental factor.

\subsection{Estimation of fatty acid}

Lipids and fatty acids play a major role in membrane biochemistry and have a direct impact on membrane mediate processes like nutrient absorption and transportation. The character and quantity of these lipids in fish vary per species and habit $[19,20]$. The grouper fish include 15 fatty acids. Seventeen fatty acids found on dorsal region of $P$. gigas, the SFA was registered as $45.30 \%$ content is the highest concentration [15]. Vignesh and Srinivasan, were observed the fatty acid contents on O. mossambicus species has much more alpha linolenic acid (C18:4) $(2.4 \mathrm{mg} / 100 \mathrm{~g})$ in head region has the $O$. mossambicus [21]. This abundant variation could be around associated to the size of the investigated fish for the separate studies or seasonal conditions at the time of the study conducted.

\section{CONCLUSION}

In general, the groupers fish are most well-liked and consumed by all the economic group of people. This nutritional composition study is able to battle with plenty of commercially consumed fish species. In this study, we have concluded the grouper fish having rich supply of protein and good fatty acids and it will facilitate to enhance the nutrition level on poor folks.

\section{Reference}

[1] Sheril Ann Shaji, Hindumathy, C.K., J. Biol. Earth Sci., 3(1): (2013) B129-B134.

[2] Ozogul Y, and Ozgoul F., Journal of Food Chemistry. 100: (2007)1636-1638.

[3] Feng Z, Ping Z, Chao S., Journal Food Chemistry. 2: (2010) 224-227.

[4] Glover C.N, Hogstrand C., J. Exp. Biol. 205: (2002) 151-158.

[5] Lowry O.H, Rosebrough N.J, Farr A.L, Randall R.J., J. Bol. Chem., 193: (1951) 265-273.

[6] Folch J, Lees M, Sloane Stanley G.H., J. Biol. Chem., 226: (1957) 497-509.

[7] Dubois M, Gilles K.A, Hamilton J.K, Rebers P.A, Smith F., Annal. Chem., 28: (1956) 350. 
[8] Guzman H.M, Jimenez C.E., Mar. Pollut. Bull., 24: (1992) 554-561.

[9] Bligh E.G, Dyer W.J., J. Biochem. Physiol., 37: (1959) 911-917.

[10] Kumaran R, Ravi V, Gunalan S, Murugan B, Sundramanickam A., Advance in Applied Science Research.3(4): (2012) 2015-2019.

[11]Eswar A, Kathirvel K, Anbarasu R, Ramamoorthy K, Sankar G, Suvitha S, Manikandarajan T., ILNS. 12(1): (2014) 21-29.

[12] Jitender Kumar, Jakhar Pal, A.K, Devivaraprasad Reddy A, Sahu N.P, Venkateshwarlu G, Vardia H.K., selected Indian Fishes. 4(5): (2012) 155-160.

[13] Ogbonnya Chukwu, Ibrahim Mohmmed Shaba., World Journal of Agricultural Sciences. 5(1): 2009.114-116.

[14] Nurnadia A.A, Azrina A, Amin I., International Food Research Journal. 18(2011)137-148.

[15] Manat Chaijan, Akkasit Jongjareonrak, Suttirug Phatcharat, Soottawat Benjakul, Saroat Rawdkuen., LWT-Food Science and Technology. 43 (2010) 452-457.

[16] Manikandarajan T, Eswar A, Anbarasu R, Ramamoorthy K, Sankar G., (IOSR-JESTFT). (2014) 32-40.

[17] Tolonen M., Vitamina and minerals in health and nutrition, Ellis Horword, London. (1990) 152-188.

[18]Fawole O.O, Ogundiran M.A, Ayandiran T.A, Olagunju O.F., Internet Journal of Food Safety. 9 (2007) 52-55.

[19] Conner W.E, (Suppl.). (1996) S 183-S 187.

[20] Czesny S, Dabrowski K, Christensen J.E, Eenennam J.V, Doroshov S.,J. Aquaculture. (2000), $189,145-157$.

[21] Vignesh R, Srinivasan M., Asian Pacific Journal of Tropical Biomedicine. (2012) S368- S372. 